\title{
交互砂州河床における水みちの形成過程に及ぼす 土砂供給と砂碟の分級の影響 \\ EFFECTS OF SEDIMENT SUPPLY AND GRAIN SORTING ON \\ LOW-WATERCOURSE FORMATION IN CHANNEL WITH ALTERNATE BARS
}

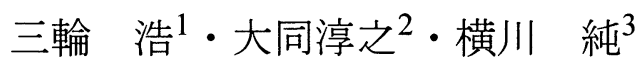 \\ Hiroshi MIWA, Atsuyuki DAIDO and Jun YOKOGAWA \\ 1正会員 工博 舞鶴工業高等専門学校助教授＼cjkstart建設システム工学科（テ625-8511 京都府舞鶴市白屋234） \\ 2正会員 工博＼cjkstart東アジア技術事務所（†613-0905 京都市伏見区淀下津町129） \\ 3 正会員 伊根町役場 農林水産課（干626-0493 京都府与謝郡伊根町字平田493）
}

\begin{abstract}
Effects of sediment supply and grain sorting on the formation process of low-watercourse in a straight channel with alternate bars are investigated by means of flume tests using uniform and non-uniform sediment. Results are summarized as follows: (1) The low-watercourse is shallow and unstable when the bed level does not vary by sediment supply, whereas the deep and stable low-watercourse is formed when the bed degradation progresses by no sediment supply. (2) The emerged bars in the non-uniform sediment bed are formed with grain sorting, and their upper and lower part mainly consists of coarse grains and fine grains, respectively. These emerged bars are more stable than those in the uniform sediment bed, and contribute to the stability of the low-watercourse. (3) The meandering wavelength of the low-watercourse increases considerably with progression of the bed degradation, and is about 2-3 times the mean wavelength of the alternate bars.
\end{abstract}

Key Words : alternate bars, low-watercourse, emerged bar, riverbed degradation, sediment supply, non-uniform sediment, grain sorting

\section{1. 緒 言}

河川には河道の形状や河床材料, 流量状況等に応じて 種々の河床形態が形成されるが，とくに，砂州河床は洪 水時には治水面が重要視され，平水時には浮州や蛇行低 水路（以下，本文では水みちと呼ぶ）の形成が生物生息 空間としての河道環境面において重要視される1)という 特性を有している.このような二面性を有する河道にお ける土砂管理を適切に行うための着眼点の一つとして, 上流からの流量や土砂供給量の変化が河道に及ぼす影響 を明らかにすることが挙げられる. 例えば，洪水時に発 達した砂州が, 平水時にどのように変動し, また, どの ような過程を辿って安定化するかを明らかにすることは， 治水と環境の両面に加え, ダム等による放流や排砂の制 御法とも関連して, 重要な課題であるといえる. また, 混合砂礫河床では分級によって河床粒度が変化するため, これが河床変動に及ぼす影響も考える必要がある. 本研 究では, 交互砂州河床における水みちの形成に着目し, これに及ぼす土砂供給条件と混合砂䃇の分級の影響につ いて検討する.

内島・早川 ${ }^{2}$ は小流量による交互砂州の変形に伴う水 みちの形成と局所洗掘の関係について考察している. 湯
城ら ${ }^{3)}$ 同様の検討を行うとともに, 水みちの形成限界 流量や変動特性について検討している. また, 清水ら ${ }^{4)}$ は交互砂州河床における水みちの形成過程を数值シミュ レーションによって検討し, 現地観測で見られた瀬や淵 の特性等との対応について考察している. これらの研究 では主として流量条件の影響に着眼点が置かれており, 土砂供給条件（上流端境界条件）による河床低下の影響 については必ずしも言及されていない.これらの研究に 対して, 道上ら ${ }^{5)}$ は平坦河床からの水みちの発生・発達 過程に及ぼす土砂供給の有無の影響を検討し, 数值シ ミュレーションによって現象の再現を試みている．また， 著者らのや寺本・辻本”は実河川を扱う際には河道を形成 した流れ場の条件とは異なる条件下での河道の応答を検 討することの重要性を指摘し，その一例として交互砂州 の発達・変形に及ぼす流量や土砂供給条件の影響を検討 しており,この中で水みちの形成・変動に関しても若干 の考察が行われている.

このように, 水みちの形成やその変動に関しては, 種々の観点から検討が行われているものの, 交互砂州河 床での水みちの形成過程に及ぼす土砂供給条件や混合砂 礫の影響については得られている成果は少なく, さらに 検討を深める必要がある. そこで, 本研究では流量一定 


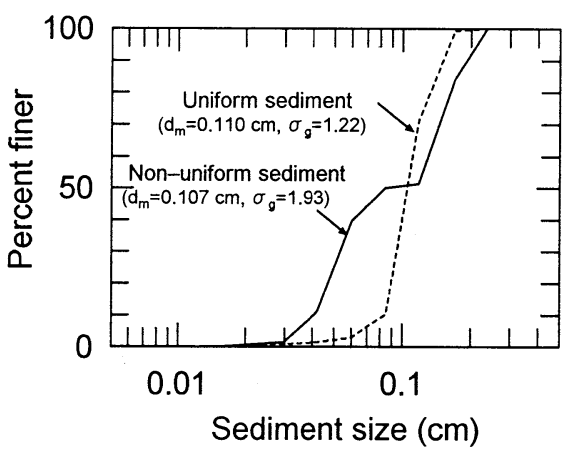

図-1 使用砂の粒度分布

の下で，給砂条件を変えた実験を行い，水みちの形成過 程とその安定性に関する検討を行う。まず，河床変動過 程を詳細に追跡し, 浮州の発生と水みちの形成過程およ びこれらに及ぼす給砂条件の影響を明確にする。ついで, 淵の移動特性と水みちの蛇行波長の変化特性について考 察する．なお，実験は一様砂河床と混合砂河床を対象と して行い，両河床における現象を対比することによって， これらに及ぼす混合砂の分級の影響についても言及する.

\section{2. 実験の概要}

実験には長さ $12 \mathrm{~m} ，$ 幅0. $2 \mathrm{~m}$ 直線可変勾配水路を用い, 水路下流端に砂止め, 上流端に整流装置と粗度付きの固 定床を設置，その間に砂を敷き詰めて長さ $11 \mathrm{~m}$ の移動床 区間を設けた. 実験にはほぼ同一の平均粒径を有する一 様砂と混合砂を用いた. 実験に使用した砂の粒度分布を 図-1に示す. 一様砂は平均粒径 $d_{m}=0.110 \mathrm{~cm}$, 幾何標準 偏差 $\sigma_{g}=1.22$ を有し, 混合砂は $d_{m}=0.107 \mathrm{~cm}, \sigma_{g}=1.93$ を有する．なお，砂の比重はいずれも2.65である.

実験は，まず河床を平坦に敷き均し，河床勾配を $1 / 60$ に設定, 移動床部上流端で横断方向に一様かつ連続的に 給砂を行いながら通水し, 交互砂州をほぼ平衡状態まで 発達させた. 停水直前に水面計を用いて水路縦断方向 $20 \mathrm{~cm}$ 間隔で水面を測定し, 停水後にレーザ一変位計を用 いて水路横断方向 $1 \mathrm{~cm}$ 間隔で河床面の縦断形状を測定し た. なお, 水路下流端から $8.35 \mathrm{~m}$ の位置を測定の原点 $(x=0)$ とし，そこから下流側7. $95 \mathrm{~m}$ の範囲を測定対象と した. ついで, この交互砂州を初期河床として, 給砂を 行う場合と行わない場合の 2 種類の条件下で流量を減少 させて通水し, 交互砂州の変形と水みちの形成過程を追 跡した. なお，この時の流量は通水初期では混合砂に対 しても全粒径が移動可能な量であり, 村本・藤田 ${ }^{8)}$ の領 域区分図において交互砂州領域の下限付近に位置する条 件である. また, 給砂を行う場合の給砂量は初期交互砂 州の平均河床高を維持する量を目安に, 予備実験で求めら
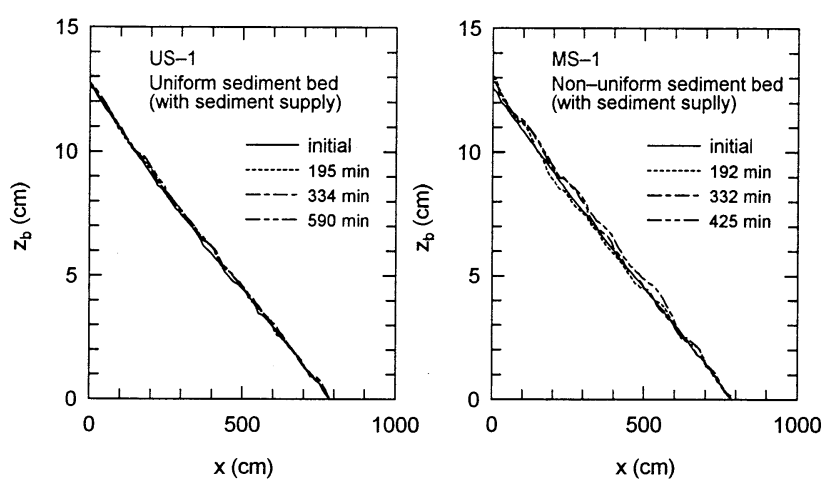

（a）給砂あり
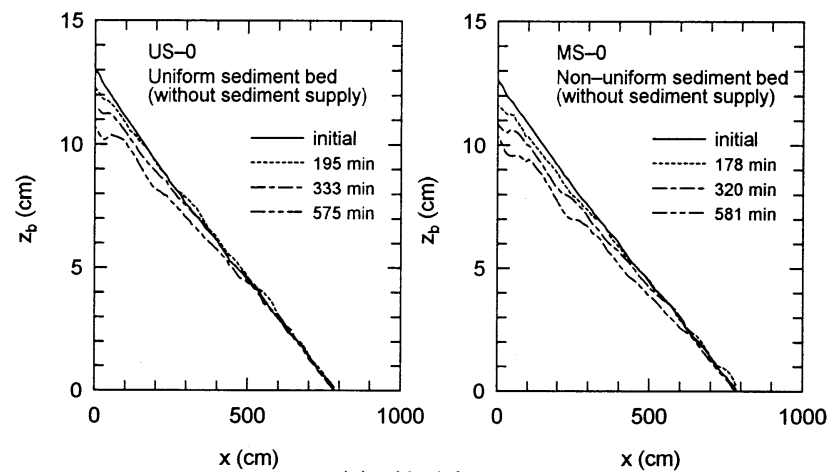

（b）給砂なし

図-2 河床縦断形状の時間変化 (左 :一様砂, 右 : 混合砂)

れた. 通水中は浮州の位置と概形, 淵の位置および流砂 方向のスケッチを随時行うとともに，水路下流端から流 出する砂を5分間隔で約1分間採取して流出砂量を測定し た. 所定の時刻に水面と河床面の測定を先と同様の方法 で行った後, 通水を再開した. 実験は, 給砂を行わない 実験で形成される水みちがおおむね安定するまで継続す ることを基本に，給砂を行う実験も同程度の通水時間と した.これらの実験条件をまとめて表-1に示す．表中，

「交互砂州 $\rightarrow$ 水みち」欄の水理量は通水開始後最初の停 水時(約30分後)のもので，「無次元掃流力」欄の括弧内 は無次元化に用いた砂粒子である. なお，本文では流量 を減少させた実験の開始時を時閒の原点 $(t=0)$ としてい る.

\section{3. 交互砂州の変形と水みちの形成過程}

\section{（1）河床縦断形状に及ぼす給砂の影響}

図-2は水みちの形成過程における横断面平均河床位の 縦断形状の時間変化を示したものである，なお，河床位 の基準は $x=795 \mathrm{~cm}$ 地点の横断平均河床である. まず，給 砂を行った場合を見ると，一様砂河床では河床位の変化 はほとんど認められない。このケースでは給砂量と下流

表-1 実験条件

\begin{tabular}{|c|c|c|c|c|c|c|c|c|c|c|c|c|c|c|}
\hline \multicolumn{2}{|c|}{ 河床形態 } & \multicolumn{6}{|c|}{ 平坦河床 $\rightarrow$ 交互砂州 } & \multicolumn{7}{|c|}{ 交互砂州 $\rightarrow$ 水みち } \\
\hline Case & 河床砂 & $\begin{array}{c}\begin{array}{c}\text { 流量 } \\
\left(\mathrm{cm}^{3} / \mathrm{sec}\right)\end{array} \\
\end{array}$ & $\begin{array}{l}\text { 給砂量 } \\
(\mathrm{g} / \mathrm{min})\end{array}$ & $\begin{array}{l}\text { 水深 } \\
(\mathrm{cm})\end{array}$ & Froude & $\begin{array}{c}\text { 次元掃流力 } \\
(\mathrm{dm})\end{array}$ & $\begin{array}{c}\text { 通水時間 } \\
\text { (min) }\end{array}$ & $\begin{array}{c}\begin{array}{c}\text { 流量 } \\
\left(\mathrm{cm}^{3} / \mathrm{sec}\right)\end{array} \\
\end{array}$ & $\begin{array}{l}\text { 給砂量 } \\
\text { ( } \mathrm{g} / \mathrm{min})\end{array}$ & $\begin{array}{l}\begin{array}{l}\text { 水深 } \\
(\mathrm{cm})\end{array} \\
\end{array}$ & Froude数 & $\begin{array}{c}\text { 無次元 } \\
(\mathrm{dm})\end{array}$ & $\begin{array}{c}\text { 帚流力 } \\
\text { (d90) }\end{array}$ & \begin{tabular}{|c} 
通水時間 \\
$(\min )$
\end{tabular} \\
\hline US-1 & \multirow{2}{*}{ 一様砂 } & 800 & 200 & 1.18 & 1.00 & 0.104 & 76 & 300 & 50 & 0.70 & 0.82 & 0.061 & - & 590 \\
\hline US -0 & & 800 & 200 & 1.16 & 1.02 & 0.102 & 7 & 300 & 0 & 0.63 & 0.96 & 0.056 & - & 575 \\
\hline MS-1 & \multirow{2}{*}{ 混合砂 } & 800 & 250 & 1.13 & 1.06 & 0.100 & 86 & 300 & 80 & 0.65 & 0.91 & 0.059 & 0.032 & 580 \\
\hline MS -0 & & 800 & 250 & 1.07 & 1.15 & 0.097 & 67 & 300 & 0 & 0.63 & 0.96 & 0.056 & 0.030 & 581 \\
\hline
\end{tabular}




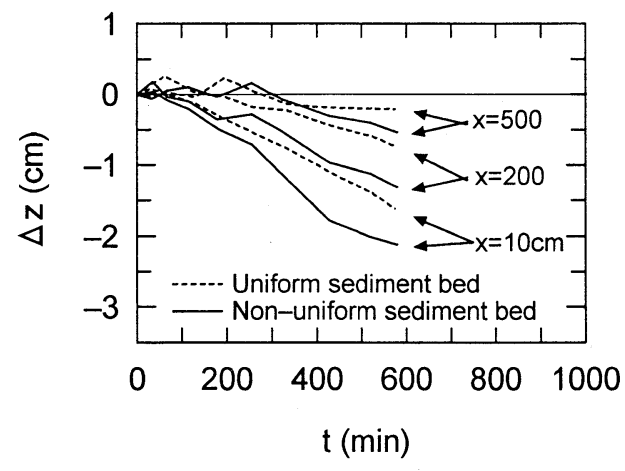

図-3 初期河床からの河床変化量の時間変化（給砂なし）

端流出砂量はほぼ釣り合っており，いわゆる動的平衡状 態が保たれているといえる。 一方, 混合砂河床では 192 分では若干の河床低下，それ以降は若干の河床上昇が認 められるが，全体としては初期交互砂州河床の縦断勾配 を保っている，つぎに，給砂を行わなかった場合を見る と, 上流から順次河床が低下し, 実験の最終段階では一 様砂河床では $x=500 \mathrm{~cm}$ 程度まで, 混合砂河床では水路下 流端付近まで河床低下が及んでいる。 これは，本実験で は混合砂河床の流砂量が一様砂河床よりも多く, 河床侵 食がより活発であったことを示している. 両河床におけ る河床の低下速度を比較するため, $x=10 \mathrm{~cm}, 200 \mathrm{~cm}$ お び500 cm地点における, 初期交互砂州を基準とした河床 変化量の時間変化を図-3に示す。これより, 河床低下は 混合砂河床の方が速く進行していることがわかる. 一般 に, 河床低下によって河床の粗粒化が進行する場合は, さらなる河床低下は抑制される. 一方, 本実験では粗砂 は池田ら ${ }^{9}$ が示した露出効果と減摩効果によって細砂よ りも移動性に富んでおり, また, 後述するように, 粗砂 の多くが比高の高い州上に堆積して浮州の形成に寄与す る傾向にある. このため, 水みち部の河床表層は相対的 に細砂の割合が大きくなっており，一様砂河床に比べて 侵食されやすく, 河床低下速度が大きい原因になってい

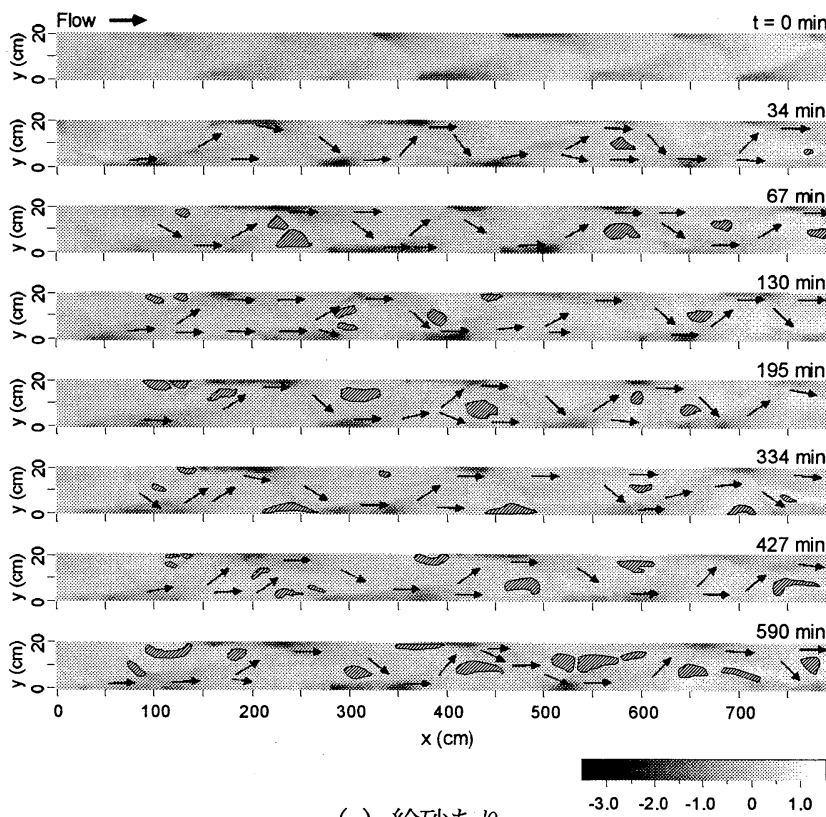

（a）給砂あり
ると推察される.

以上のように，本実験では，給砂を行った場合は平均 的には河床低下をきたさない状態で水みちが形成され， 給砂を行わなかった場合は河床低下を伴って水みちが形 成されている. また, 混合砂河床の場合は砂粒子の分級 の影響も現れる。これらについて次節で詳細に検討する.

\section{（2）水みちの形成過程}

図-4は一椂砂河床における河床形状と流砂方向の時間 変化を示したものであり， $t=0$ は初期交互砂州形状であ る. 河床形状は初期交互砂州の平均河床面を基準として そこからの偏差で表されており，色が濃いほど低位であ る.また，実線で囲まれた部分は浮州であり，矢線は通 水中のスケッチから得られた流砂の向きを示している. 実験の観察によると, 通水開始後, 深掘れから下流側砂 州の前縁に向かう流れが卓越し，河床の高い部分の流れ は弱い，この卓越する流れは初期交互砂州を形成させた 大流量時よりも側壁に向かう角度が大きく，この流れに よる流砂の砂州前縁への堆積によって砂州は前縁を側壁 側に張り出しながら発達し, 波長も若干増加した. なお, この段階では河床全体がほぼ冠水しており, 水みちは形 成されていない，通水初期の段階ではこのような現象が 給砂の有無にかかわらず見られた．さて，給砂を行った 場合, 交互砂州河床に起因寸る深掘れ部からの流砂が比 高の高い州上に堆積し，通水開始後34分や67分に見られ る浮州が形成される.これに伴って部分的に浅い水みち が形成されるが，浮州は水面から数粒径程度しか出てい ないため，水みちの水流によって侵食され易い，これに よって河床が冠水すると砂州は下流へ移動し, 深掘れか らの流砂の州上への堆積によって再び浮州が形成, これ に伴って新たな水みちが形成される。 このように，浮州 はかなり不安定で, 絶えず発生と消滅を繰り返し, これ に伴って水みちも変動する. 本実験では, 浮州形成に伴 う水みちの河床侵食の進行よりも浮州の形成・侵食が卓
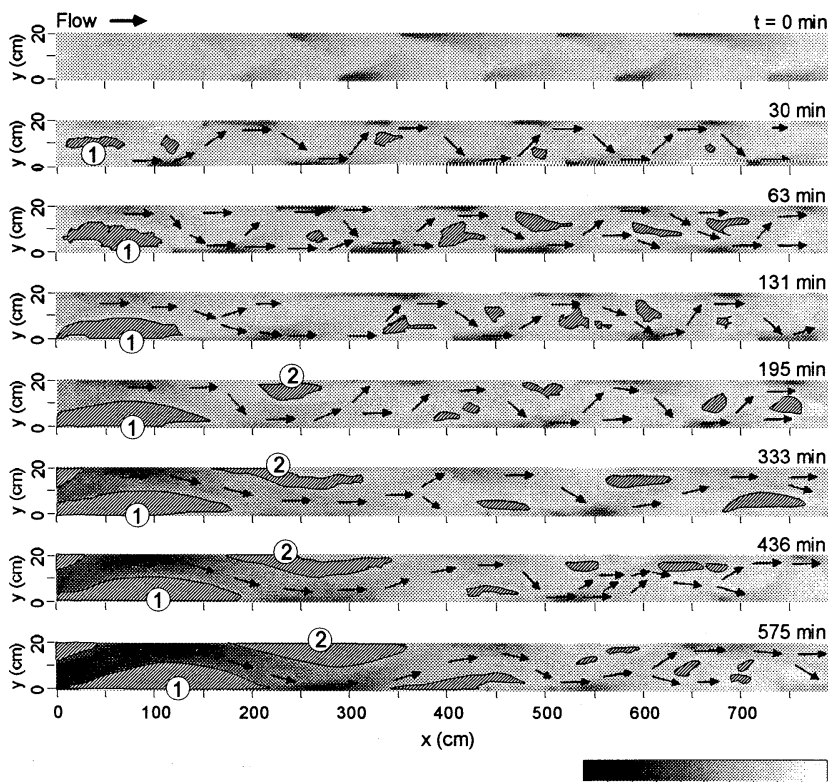

(b) 給砂なし

図-4 河床形状と流砂方向の時間変化（一様砂河床） 


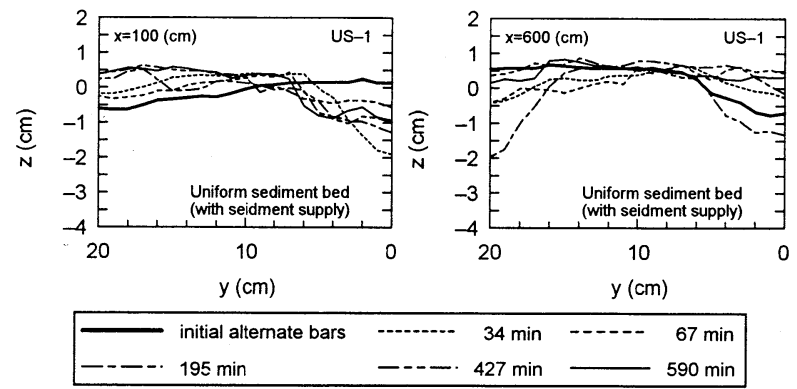

(a) 給砂あり

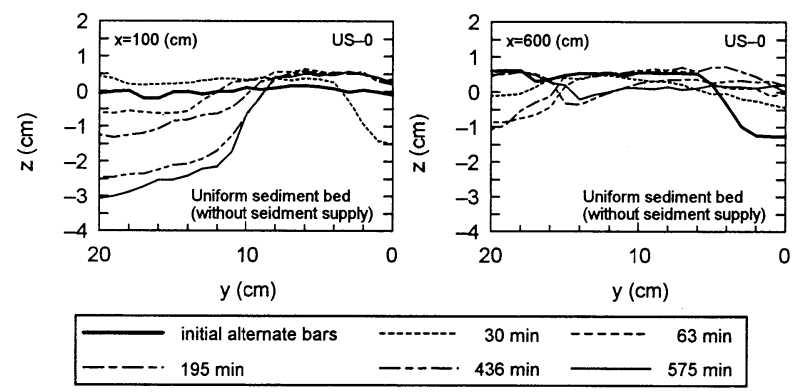

(b) 給砂なし

図-5 河床横断形状の時間変化（一様砂河床）

越し，水みちが変動したが，清水らののシミュレーショ ンでは水みちの河床侵食が卓越し, 深掘れ部への流れの 集中と相まって安定した水みちの形成が示されている. 河道全体としての河床低下がない状況でのこのような水 みち形成過程の相違を生む原因については今後明らかに する必要がある. 一方, 給砂を行わなかった場合, 通水 開始後30分経過時点で浮州の形成が見られ，63分時点で は上流側に相対的に規模の大きい浮州(1)認められる.

この浮州11は上流からの河床低下に伴う左岸側への流水 の集中による河床侵食によって安定している. 時間の経 過とともに河床低下は進行し, 水みちは深く安定したも のに発達する.195分には規模を増した浮州(1)と新たな 浮州(2)の形成によって，明瞭な水みちが形成されている

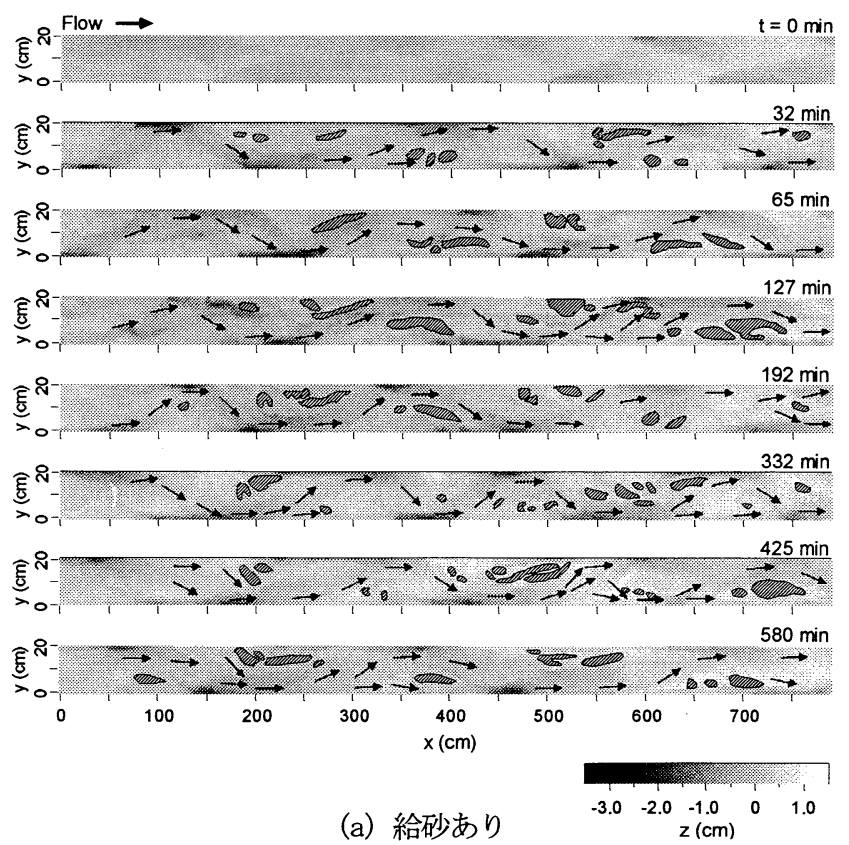

ことがわかる.この上流側から発達した水みちは河床低 下の進行に伴って安定性を増しながら順次下流に延びて 行く。このような安定した水みちに対して, 河床低下が 及んでいない下流側では部分的に浮州が現れ，浅い水み ちが形成されている. 給砂を行った場合と同様, 下流側 の浮州はかなり不安定で, 絶えず発生と消滅を繰り返し, 水みちも変動している.

図-5は $x=100 \mathrm{~cm}$ よび $600 \mathrm{~cm}$ 地点の河床横断形状の時 間変化を示したものである. 給砂を行った場合は，いず れの時刻においても側岸に墚掘れ部があり，また，図一 3(a)に見られるようにこれが移動しており，河床は交互 砂州の特性を示していることがわかる. ただし，本ケー スでは浮州が出現しており, 河床全体が水没していると きの交互砂州とは必ずしも同一視できないと考えられる. すなわち, 浮州が現れるまでは流水と河床の相互作用に よって砂州は変形するが，浮州が現れると，これと水み ちとの相互作用によって砂州は変形すると考えられる.

一方, 給砂を行わなかった場合は, $x=100 \mathrm{~cm}$ 地点の図か ら左岸側で水みちが発達する様子がわかる。 なお，下流 側の $x=600 \mathrm{~cm}$ 地点では河床低下が及んでいないため, 給 砂を行った場合と同様の傾向を示している.

図-6は混合砂河床における河床形状と流砂方向の時間 変化を示したものである. 実験の観察では, 浮州が現れ るまでの砂州の変形性状は給砂の有無にかかかわらず一様 砂河床の場合と同様であった. さて, 給砂を行った場合, 通水開始後 32 分時点で浮州の形成が見られるが，これら の浮州を含む非流砂域は比較的安定で，192分時点まで 水みちの変動は抑えられている．前節で述べたように, この時点までの河床は全体に若干の低下傾向にあり，こ のような場合には水みちは比較的安定であるといえる.

これ以降425分までは河床は全体に若干の上昇傾向にあ り, 砂州の移動に伴って浮州は発生と消滅を繰り返し, 水みちも変動していることがわかる. なお，425分以降 は先の河床上昇期に比べると水みちの変動は小さく，ま
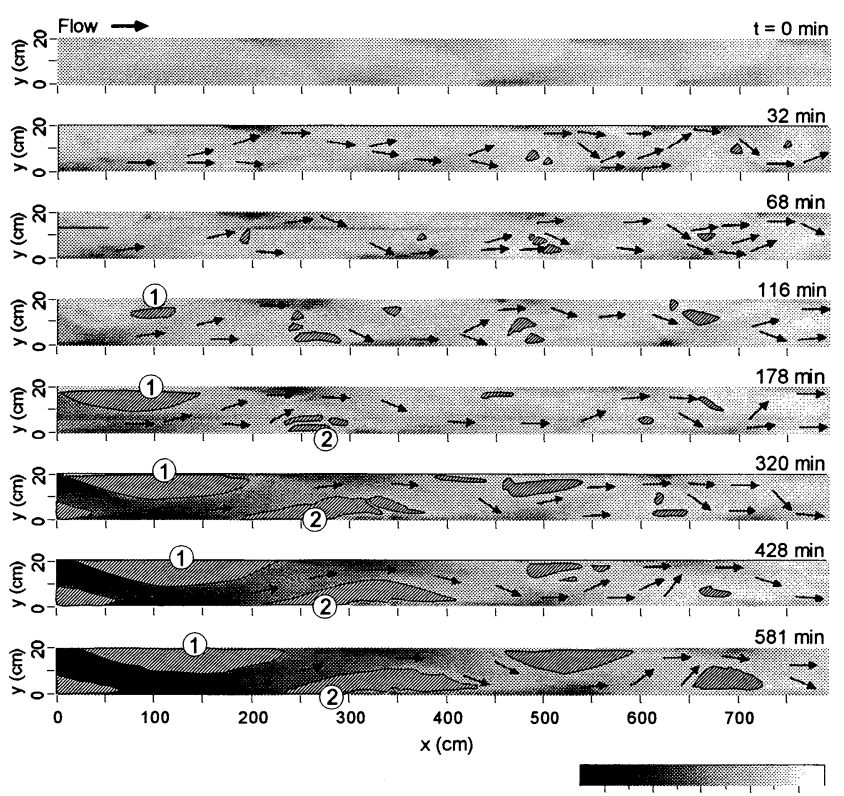

（b）給砂なし

図-6 河床形状と流砂方向の時間変化（混合砂河床） 

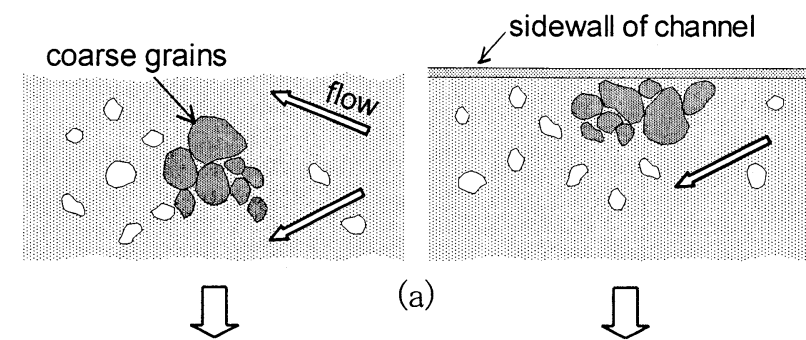

(a)
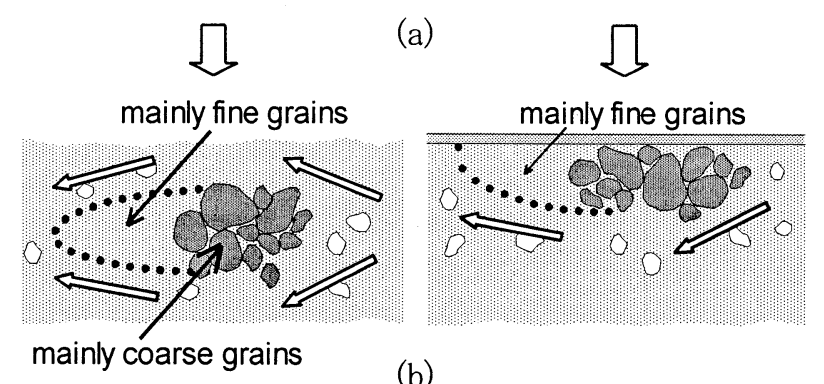

(b)

図-7＼cjkstart混合砂河床における浮州の形成過程

た，淵の移動量も少ない，一方，給砂を行わなかった場 合も通水開始後の早い段階から浮州を含む非流砂域は比 較的安定しており, 水みちの変動は一様砂河床の場合よ りも抑えられている. 116分時点の浮州(1)は河床低下に 伴うものであり, この後, 河床低下の下流への進行に 伴って, 浮州(2)は規模を増しながら安定化する. この時 点では下流側ではまだ浮州が発生と消滅を繰り返してい るが，河床低下の進行に伴って上流側から順次浮州が安 定化し，水みちは一本化するようになる．本実験では混 合砂河床の方が一椂砂河床よりも流砂量が多く，これが 深い水みちの形成に寄与していると思われる. 以上のよ うに, 河床低下によって深く, 安定した水みちが形成さ れること, また, 混合で形成される浮州は水みちの変動 を抑える働きをしていることがわかる.

さて, 混合砂河床で形成される水みちは河床の上昇や 低下の影響を受けているものの, 一様砂河床の場合より も全体としてその変動は抑えられている. これは浮州の 形成とその安定性に起因しており，砂粒子の分級がこれ らに影響を及ぼしていると考えられる。図一7は本実験で の浮州の形成過程を模式的に表したものである. すなわ ち，場所的な掃流力の不均一によって粗砂が堆積寸ると， 流水は粗砂の堆積帯を避けるように流れ，堆積帯は浮州 化する (d)．粗砂による唯積帯の下流側周迭は掃流力が 低下するため砂は堆積しやすくなるが, 粗砂はこの堆積 帯付近に堆積し, 細砂はこれより下流側まで流送されて 堆積する.これによって浮州は規模を増す (b). また, 給砂を行わなかった場合には水みちの河床侵食の進行に 伴って浮州はその規模を増大させ，より安定したものに 発達する. 浮州の上流側に粗砂が多く堆積しているため 侵食されにくく, 浮州は比較的安定している. また, 浮 州が発生と消滅を繰り返した場合でもその周期は一様砂 河床の場合より長い傾向にあることが確認されている. 以上のことより, 砂粒子の分級現象は, これを伴う浮州 が安定であることを介して水みちの変動抑制に寄与して いるといえる.

\section{（3）水みちの絉断形状}

図-8は河床横断方向最深河床位の縦断形状の時間変化
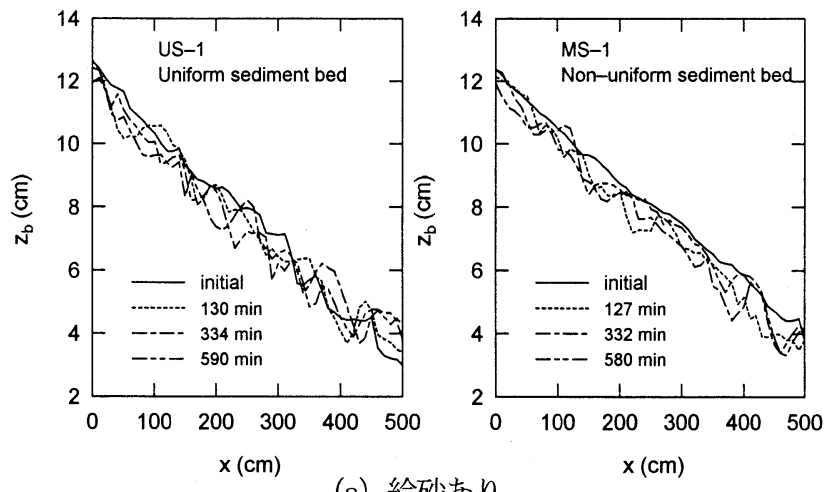

（a）給砂あり
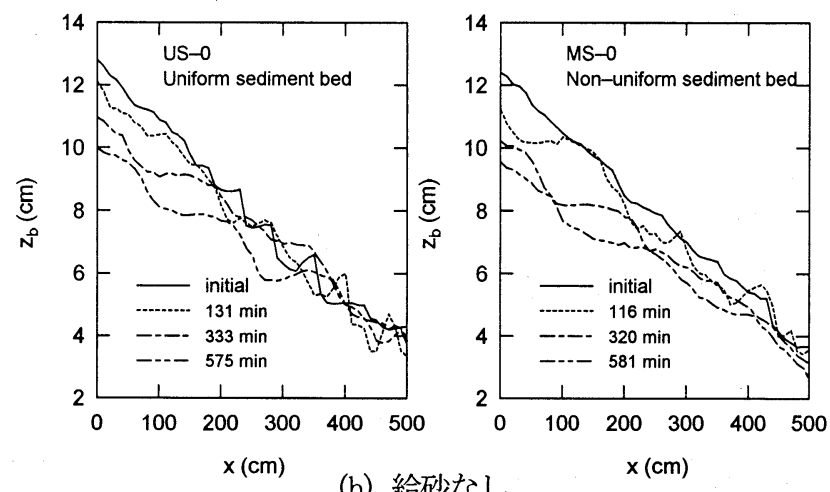

(b) 給砂なし

図-8 水みち縦断形状の時間変化 (左 : 一様砂, 右 : 混合砂)

を示したものである. 清水ら ${ }^{4}$ は河床低下をきたさない 条件下での交互砂州河床における水みち形成のシミュ レーションから，水みちでは落差の大きな瀬と緩やかな 勾配の淵が形成されることを示している，一方，同図 （a）より, 河床低下をきたさなく, 水みちが変動する場 合でもこのような現象が見られる．また，同図(b)より， 河床低下をきたしていて, 水みちが安定している場合は このような現象が顕著に現れることがわかる.

\section{4. 淵の移動と水みちの蛇行波長の特性}

図-9は通水開始後, 最初の河床測定時（約 30 分経過 後）に確認された淵のその後の移動状況を示したもので ある. まず, 一様砂河床の場合を見ると, 給砂を行った 場合はいずれの淵も移動を続けるが, 給砂を行わなかっ た場合は上流側の淵から順次移動が停止し, 固定化する ことがわかる。これは水みちの安定化と対応しており， 淵は水みちが変動している場合は移動するが，水みちの 安定化に伴って固定化するようになる. 一方, 混合砂河 床の場合を見ると, 給砂を行った場合は, 通水開始から 200分程度の期間では淵の移動量は少なくむしろ固定化 の状態にある.これは，この期間では河床は若干の低下 傾向にあり, 形成された水みちは浅いものの比較的安定 していたためである. しかし, その後の水みち変動の活 発化に伴って淵は移動するようになる. 一方, 給砂を行 わなかった場合は, 通水開始直後から水みちは比較的安 定して発達したため, とくに通水初期における淵の移動 速度は一様砂河床の場合よりも小さく抑えられている.

図-10は水みちの蛇行波長の平均值と標準偏差の時間 変化を示したものである. ただし, 河床低下を伴った水 

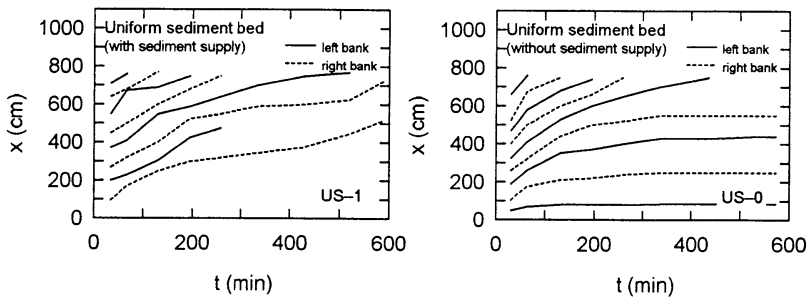

(a) 一样砂河床
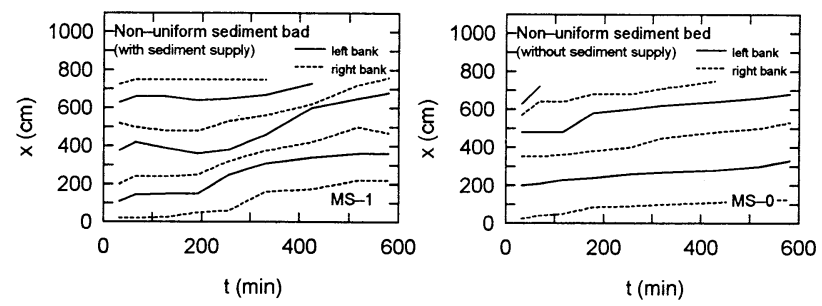

（b）混合砂河床

図-9 淵の移動状況 (左 : 給砂あり, 右 : 給砂なし)

みちの蛇行波長はの記号で区別している. また，時刻0 の值は初期交互砂州の平均波長である. 同図より, 給砂 の有無にかかわらず，河床低下のない場合は通水初期の 交互砂州の変形に伴って蛇行波長は増加し, その後水み ちの変動に呼応して, 初期交互砂州の波長の1.5〜2倍程 度の範囲で変動する. 一方, 河床低下を伴う場合の蛇行 波長は水みちの形成の早い段階からかなり長く, 初期交 互砂州の波長の2 3 倍程度である.

淵の固定化や水みちの蛇行波長は河道環境を検討寸る 際の重要な要素であり, 今後これらに対する条件の明確 化等, 定量的な把握が必要である.

\section{6. 結 言}

本研究では, 小流量時の交互砂州の変形と水みちの形 成過程に及ぼす土砂供給の影響と砂粒子の分級効果につ いて検討した. 本研究で得られた結果を以下に要約する. （1）砂州河床における水みちは浮州の形成をきっかけと して形成されるが，その後の状況は土砂供給の影響を強 く受ける. すなわち, 土砂供給によって平均河床として の河床低下がない場合は, 浮州は不安定で発生と消滅を 繰り返すため, 水みちは浅く, 変動する. これに対し, 土砂供給がなく，上流から河床低下が進行する場合は, 浮州は安定化し, 水みちも深く, 安定したものとなる.

（2）混合砂河床では, 浮州は砂粒子の分級を伴って形成 され，その上流部は粗砂が多く，下流部は細砂が多い。 また, この浮州は一様砂河床よりも安定しており, 水み ちの変動抑制に寄与している.

（3）鿬床河川に見られる水みちにおける落差の大きな瀬 と緩やかな勾配の淵の形成は，河床低下をきたしていな く，水みちが変動している場合でも見られ，河床低下に よって水みちが安定する場合はより明確に現れる.

（4）河床低下がない場合は淵は移動を続けるが，河床低 下が進行する場合は水みちの安定化に伴って淵の移動は 停止する傾向にある.

（5）水みちの蛇行波長は，河床低下がない区間では水み ちの移動に呼応して初期交互砂州波長の1.5〜2倍程度の
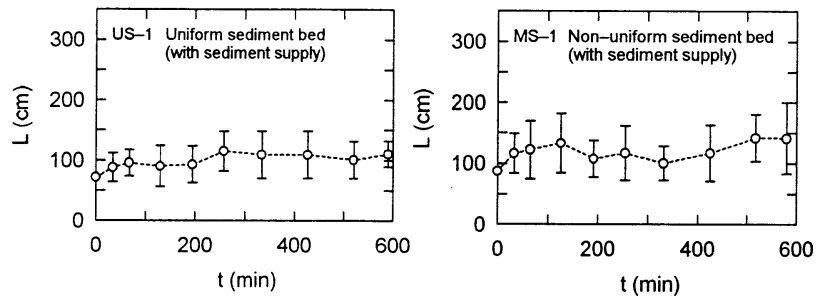

（a）給砂あり
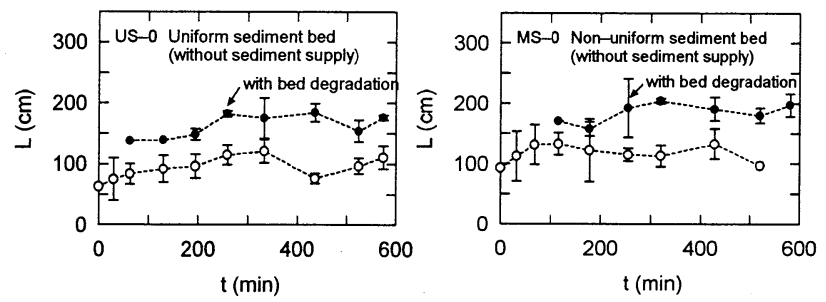

（b）給砂なし

図-10 蛇行波長の時間変化 (左 : 一様砂, 右: 混合砂)

範囲で変動するが，河床低下を伴う範囲では水みち形成 の早い段階からかなり長く，2３倍程度となる.

本研究では流量条件の影響は扱っていないが, 河床材 料との関係から，これも重要な視点である. とくに，混 合砂の場合はその粒度構成によって流砂状況が異なり， これが水みちの形成に影響を与える可能性がある.これ らの検討については今後の課題である.

謝辞 : 本研究は日本学術振興会科学研究費基盤研究(C) (課題番号: 12650522, 研究代表者: 三輪 浩) の補助 を受けて行われた，記して謝意を表します。

\section{参考文献}

1）例えば，田代 喬，辻本哲郎：河床擾乱頻度を指標とし た生息場評価による瀬・淵構造の変質に関する考察, 水 工学論文集, 第46巻, pp. 1151-1156, 2002.

2）内島邦秀, 早川 博 : 流量が減少した場合の交互砂州の 変形特性，第31回水理講演会論文集，pp. 68.3-688，1987.

3）湯城豊勝, 芦田和男, 江頭進治, 岡部健士 : 低水路の形 成と変動機構, 水工学論文集, 第36巻, pp. 78-80, 1992.

4）清水義彦, 長田健吾, 高梨智子 : 交互砂州河道における 低水路形成と河岸侵食に関する数值解析, 水工学論文集, 第48巻, pp. 1027-1032, 2004.

5）道上正規，藤田正治，日下部重幸 : 水みちの発生・発達 過程の実験とシミュレーション, 水工学論文集, 第 39 巻, pp. 613-618, 1995.

6）三輪 浩，横川 純，奥野敏也，中澤文也 : 交互砂州河 床の変動に及ぼす流量および給砂量の影響, 第58回土木 学会年次学術講演会講演概要集 II, pp. 325-326, 2003.

7）寺本敦子, 辻本哲郎：流量, 土砂流入条件が砂州の変動 に及ぼす影響の一考察，河川技術論文集；第 10 巻， pp. 273-278, 2004.

8）村本嘉雄, 藤田裕一郎：中規模河床形態の分類と形成条 件, 第22回水理講演会論文集, pp. 275-282，1978.

9）池田 宏，伊勢屋ふじこ: 混合砂れきの流送に伴う縦断 的分級，第30回水理講演会論文集，pp. 217-222， 1986.

(2004.9. 30 受付) 